\title{
Dams Safety: Inspections, Safety Reviews, and Legislations
}

\author{
Nasrat Adamo', Nadhir Al-Ansari², Varoujan Sissakian ${ }^{3}, J_{a n}$ Laue $^{4}$ \\ and Sven Knutsson ${ }^{5}$
}

\begin{abstract}
When a dam is built, its safety becomes a constant concern for the owner, the public and for governments. Therefore, continuous observation through routine inspections and safety reviews become necessary. Acting as protectors of public safety, governments and professional organizations save no effort in the promulgation of legislations and laying out guidelines for such inspections and reviews. These issues are discussed here starting with the basic first step of visual inspections by the operators and the follow up of detailed safety reviews by specialists. Careful visual inspections assisted by instrumentation measurements may reveal an early negative issue such as, but not limited to, increased seepage, increased uplift pressure, signs of weakness like cracking in the body of the dam, or dams' slope sloughing, and even damaged hydraulic control equipment. Documenting and reporting these observation helps in taking remedial measures in good time and may lead to more intensive safety reviews. Suggested check lists for the inspection engineers are given here, but these may be tailored for each dam according to its needs. These lists cover issues common to both embankment and concrete dams, and include other specific issues related to each type of them. Metal equipment take their share by listing such areas as corrosion, fatigue and cracking, tear, and wear and so on. Instrumentation measurements are also given their due consideration by giving brief mention of types of measurements needed and points to be observed in instrumentation control work. Finally, guidelines, rules, and
\end{abstract}

\footnotetext{
1 Consultant Dam Engineer, Sweden.

2 Lulea University of Technology, Lulea 971 87, Sweden.

${ }^{3}$ Lecturer, University of Kurdistan Hewler and Private Consultant Geologist, Erbil.

${ }^{4}$ Lulea University of Technology, Lulea 971 87, Sweden.

${ }^{5}$ Lulea University of Technology, Lulea 971 87, Sweden.
} 
legislations for Dam Safety Reviews are generally discussed giving examples from four countries in the world.

Keywords: Normal Human Caused Incidents, Extraordinary Human Caused Incidents, SCADA Systems, ICS System, Software, ICT Technology, Cyberspace, digital technology, Remote Control, hackers, terrorism.

\section{General}

Dams are built to serve useful purposes, but as all man-made structures they need constant attention to increase their service life, on one hand, and to remove any potential hazard they may present on the other. The assessment of dams' safety must be a continuing effort which requires the establishment of periodic inspection and examination routines followed by technical evaluation of any anomaly that may appear. Such evaluation becomes then the basis of any future action to eliminate the source of such anomaly and restore conditions to normal again. The extent and depth of this evaluation and remedial actions depend on many factors that contribute to the degree of safety of dams, these are:

- Dam's hazard classification with respect to loss of life and material losses.

- Size of the dam, its type, its height, and the volume of reservoir it impounds.

- Dam's behavior and performance during past years and the engineering judgment on its integrity.

The safety review of any dam takes special weight during its impoundment and just after first filling and shall continue in the following years after its commissioning. First filling of any dam reservoir may be considered as the most critical phase of the dam's life. The dam structures in this period adjust themselves to the newly applied loads. The foundation being subjected to new hydraulic loads and flows of water should adapt to the new conditions, while seepages through dam body should develop to its prescribed stable state and must be inside safe limits. At the same time, the body of the dam will apply its full weight on the foundation, uplift force being accounted for, the foundation must accommodate the new loads and settle within the calculated values expected, and as a whole the dam should adjust itself to any possible differential settlement. Not only that, but all appurtenant structures should operate in a smooth way as prescribed in their design.

Having passed the first filling phase, comprehensive safety reviews must continue periodically to ensure the application of the required safety standards, or in case of any deviation, to restore conditions back to normal. During the time between such reviews, continuous inspections and monitoring of the dam should be made at short intervals. All observations and obtained data including instrumentation recordings are to be tabulated and analyzed and kept for the next safety review; unless major threat is observed, in which case an urgent action is called for.

Strict inspection and review routines of dams' safety conditions were particularly re-enforced during the seventies of the last century by governments as a result of the major disasters at Malpasset (France), Vajont (Italy), and Baldwin Hills (United 
States); and in several countries new or revised laws for supervision of safety of dams and reservoirs were enacted. The Dam Inspection Act, U.S. Congressional Public Law 92-367, signed into law August 8, 1972, authorized the Secretary of the Army, acting through the Chief of Engineers, to undertake a national program of inspection of dams. Under this authority, the Corps of Engineers has

i. compiled an inventory of Federal and non-Federal dams;

ii. conducted a survey of each State and Federal agency's capabilities, practices, and regulations regarding the design, construction, operation, and maintenance of dams;

iii. developed guidelines for safety inspections and evaluations of dams; and

iv. formulated recommendations for a comprehensive national dam safety program.

The new French regulations require annual inspections of dams. Recognizing that the Malpasset and Vajont tragedies happened during reservoir filling, the French rules impose especially strict inspection requirements in the initial impoundment stage. They establish and regulate the rate of reservoir filling, and they call for weekly instrumentation readings, and require inspections at daily, weekly, and monthly intervals. Regular surveillance of the reservoir's peripheral areas is included. A report on the performance of the dam and reservoir is to be ready after 6 months.

In the United Kingdom, the Reservoirs Act of 1975 was written as an updating of 45-year-old rules that were put into effect after the British dam failures at Dolgarrog and Skelmorlie in 1925. The new law provides authority for regulators to intervene when an inspecting engineer's report has not been given adequate response. In such cases, the officials are empowered to effect the necessary corrective measures and to bill the costs to the owner. The British regulations also call for certificates which specify limits of safe reservoir operating level. An inspection is to be conducted by an independent qualified civil engineer not later than two years after issuance of the "final completion certificate," and at proper intervals thereafter. The Bureau of Reclamation considers two years to be the maximum time interval between field (onsite) examinations and six years to be the maximum time interval between evaluations. Also, Regional personnel make periodic examinations devoted primarily to operation and maintenance [1]. 


\section{Scope of Dam's Safety Reviews}

The frequency of these reviews depends on the age of the dam, last years' review reports findings and previously discovered problems, in addition to solutions taken to remedy them. As a normal interval, this may be once each five years for intensive reviews, but intermediate reviews may also be warranted in between. All this depends on the dam present conditions and its hazard classification.

Safety reviews have to be carried out by outside professional and specialized Engineer and includes disciplines of all branches of hydrology, geology and engineering relevant to dam safety issues.

The scope of any dam's safety review shall cover all issues, directly or indirectly, related to its location, its design, its construction, and performance and; so, may include, but not limited to the following work:

i. Design of the dam and its appurtenant structures is reviewed to assess their current performance compared to their intended performance and mark deviations, if any.

ii. Previous years' inspection reports are reviewed while original data and adequacy of the design criteria are checked to see if the behavior of the dam as indicated from these reports continues to be in conformity with required safety standards or not. Moreover, if these reports reveal changes of any of the loading conditions during the previous period, then behavior of the dam's structures is reviewed to be sure that such changes have not encroached on the factors of safety stipulated in the original design. In cases of deviation from the original factors of safety, new analyses have to be performed by incorporating the new set of data, and preferably using updated design theories and analysis tools and procedures to get the actual factor of safety. When serious dam safety concerns requiring immediate solution are discovered, then prompt action to bring up these concerns to the attention of the management must follow, and the solutions themselves have to be prescribed for mitigating safety conditions.

iii. Changes which occur in the environ of the reservoir may necessitate reexamination of the dam design or its operation and of the surveillance program. Hazards that worth studying are:

1. developed surface of failure of reservoirs slopes resulting from the alternating filling and emptying procedure or after earthquakes,

2. industrial activities carried out in the vicinity of the dam such as deep excavation, trenching, tunneling, building construction, or storage of explosives or flammable materials are also worthy of consideration.

As has been mentioned already, safety reviews shall depend, among other things, on the use of all the materials accumulated from onsite inspections; including visual observation of all structures made in conjunction with instrumentation monitoring to adequately assess the safety of a dam. Visual observation can readily detect indications of poor performance such as offsets, misalignment, bulges, depressions, seepage, leakage, and cracking. More importantly, visual observation can detect 
variations or spatial patterns of these features. Most visual observation provides qualitative rather than quantitative information, while instruments provide detailed quantitative information. Visual observation and instrumentation data are natural supplements and when taken together they provide the primary means for the reviewing engineers to evaluate the overall safety of a dam [2].

\section{Areas for Dam Safety Considerations}

Past accumulated experience and lessons learned from failures of hundreds of dams over past history highlight dam safety issues that should be examined and attended to in routine inspections and in safety reviews.

Generally, an important special area of concern is the geological conditions of foundation which may not be as competent as would be desired for the type or size of the dam. Deficiencies in the form of shearing planes, compressible or soluble materials, low peak or residual shear strength of seems of weak materials such as clay or faults filling materials my lead to various forms of potential failures mechanisms such as: large settlement of the dam and loosing freeboard, differential settlement and cracking, slides, increased seepage and excessive uplift. These consequences; however, may not be associated with the quality of the foundation rock only, but they can be exasperated by inadequate foundation treatment, or by regional subsidence caused by extraction of ground water or hydrocarbons, collapse of foundation soils caused by subsequent wetting. In many cases, seepage through foundation can cause piping of solid material or the dissolution and erosion of soluble material. An extensive treatment of dam safety issues related to geological factors has been presented recently in an article by the authors which illuminates many aspects of such problems that can influence dams' safety [3]. Having an open eye for any anomaly stemming out of these factors during operation merits special consideration and study.

Another area of concern that needs the reviewing engineer's attention may have roots in hydrological and hydraulic factors related to the design and performance of spillways and outlet works. They can emerge from inadequacies caused by; underestimating the inflow design discharge due to either; insufficient hydrological data used in the design, or - faulty hydraulic design. Overtopping in such cases is one possible outcome unless an auxiliary or emergency spillway is constructed. The emergency spillway itself should have adequate capacity, and in the absence of any proof of such adequacy, except for original hydraulic modelling warrants special attention by the reviewing engineer as such a spillway would be tried for the first time without previous knowledge of its efficiency.

Other problems can arise from restriction of tail water level by accumulation of gravel deposits and therefore reducing the outlet capacity or, in other cases the degradation of the downstream channel which may threaten and cause failure of downstream protection or wing walls. Stilling basins can accumulate rock, gravel, or debris and result in faulty hydraulic performance. In high velocity spillways or outlets, broken concrete or offsets in concrete surfaces can lead to dangerous 
cavitation and failure [4]. Pinpointing all such issues and suggesting their solutions remains as one of the main targets of any meaningful safety review.

Moreover, structural issues may lead to safety hazards due to cracking and displacement of concrete structures, while improperly designed or clogged filters and drainage layers, and obstructed drainage wells and underdrains can lead to excessive uplift and to sliding. Structural failure in a conduit, tunnel, or other conveyance structure causing obstruction of the flow or improper operation of the appurtenant structures can lead to overtopping. In many cases, rapid draw down of a reservoir may endanger the stability of the dam itself or the sides of the reservoir, and it may cause flooding of downstream communities. This can result from siltation of the reservoir and changes in downstream conditions. Safety reviews, therefore, have to detect possible changes in the reservoir and in the downstream conditions that may lead to changing the operation rules of the dam to eliminating sources of such dangers. Older dams should be given serious attention and need more frequent checks and reviews since their safety hazards tend to increase with time as consequence of materials deterioration, aging of equipment, and accumulated effects of aforementioned defects.

Last but not least, post-earthquake safety inspections of dams take special importance in establishing any changes of dam conditions and discovering damages; so to be able to draw up rehabilitation plans and remove causes of danger. General summary of dams safety concerns is presented in Table 1 for better clarification. The outcome of inspections and safety reviews lead in many cases to mitigation actions; such as adding auxiliary spillway, dredging of the downstream reaches, or modifying outlets stilling basins, and can lead to extensive upgrading and repairs which prove the value of careful inspections and through safety reviews. 
Table 1: General areas of Dam Safety Concerns.

\begin{tabular}{|c|c|c|c|c|}
\hline & $\begin{array}{c}\text { Area of } \\
\text { Examination }\end{array}$ & $\begin{array}{l}\text { Type of } \\
\text { Dam }\end{array}$ & Source & Remarks \\
\hline \multirow[t]{9}{*}{1} & \multirow{4}{*}{ Design } & \multirow{4}{*}{ All } & $\begin{array}{c}\text { Incomplete or incorrect design data or } \\
\text { criteria, }\end{array}$ & \\
\hline & & & Incomplete foundation investigations. & \\
\hline & & & $\begin{array}{l}\text { Failure to define all probable loading } \\
\text { conditions and failure modes }\end{array}$ & \\
\hline & & & $\begin{array}{l}\text { Incomplete materials investigation and } \\
\text { testing. }\end{array}$ & \\
\hline & \multirow{5}{*}{ Construction } & \multirow[t]{2}{*}{ Concrete } & $\begin{array}{l}\text { Improper or incomplete foundation } \\
\text { treatment, whether by using cutoffs or } \\
\text { drainage wells; this will lead to excessive } \\
\text { seepage and uplift on the dam base and } \\
\text { may lead to erosion and suffusion of } \\
\text { foundation or can result in sliding failure }\end{array}$ & $\begin{array}{l}\text { This possibility is } \\
\text { highlighted if } \\
\text { foundation } \\
\text { contains shearing } \\
\text { planes or contain } \\
\text { fines or soluble } \\
\text { materials }\end{array}$ \\
\hline & & & $\begin{array}{l}\text { Incorrect choice of aggregates leading to } \\
\text { alkali reactivity and sulfate attacks. wrong } \\
\text { methods of placemen and joints treatment }\end{array}$ & \\
\hline & & \multirow[t]{3}{*}{ Earth fill } & $\begin{array}{l}\text { Improper or incomplete foundation } \\
\text { treatment, whether by using cutoffs or } \\
\text { drainage blanket; this will lead to excessive } \\
\text { seepage and uplift on the dam base and } \\
\text { may lead to erosion and suffusion of } \\
\text { foundation }\end{array}$ & $\begin{array}{l}\text { This possibility is } \\
\text { highlighted if } \\
\text { foundation } \\
\text { contains shearing } \\
\text { planes or contain } \\
\text { fines or soluble } \\
\text { materials }\end{array}$ \\
\hline & & & $\begin{array}{c}\text { Failure to get the required compaction } \\
\text { densities, }\end{array}$ & \\
\hline & & & $\begin{array}{l}\text { Failure to control placement water content, } \\
\text { which can cause high settlement or } \\
\text { differential settlement, piping, and } \\
\text { shearing failures in embankment dams, }\end{array}$ & \\
\hline 2 & \multirow{4}{*}{$\begin{array}{l}\text { Reservoir } \\
\text { Margin } \\
\text { Defects }\end{array}$} & \multirow{4}{*}{ All } & $\begin{array}{c}\text { possibility of landslides formation due to } \\
\text { faulting }\end{array}$ & \\
\hline & & & Seismic or landslides induced waves & \\
\hline & & & Reservoir shores erosion & \\
\hline & & & $\begin{array}{l}\text { Reservoir's rim tightness and reservoir } \\
\text { failure due to piping. }\end{array}$ & \\
\hline
\end{tabular}




\section{Routine Inspection as First Step in Dam Safety Monitoring}

\subsection{General}

Visual examination, measurements and routine checking of dams' performance are important parts of the dam monitoring work. Such monitoring is the first step in any safety evaluation process of the dam. This examination taken together with the follow up of instruments recordings and other measurements should bring to the attention of an experienced inspector any anomaly or unusual behavior of the dam and its appurtenant structures.

Such things which may be observed are unusual settlement, discoloration or increase of seepage water, any new wet spots or leaks and embankment sloughing. Such occurrences should bring alarm to the inspector who should not only describe and document such cases in detail, but act promptly to bring them to the attention of the higher technical level of management. In many known cases, observation programs were diligently performed but subsequent neglect and inaction resulted in further incidents and damage which could have been averted. The selection of inspectors is of paramount importance since experience and diligence of the inspector can play greatly in avoiding major incident in time.

Safety of dams can be threatened by so many factors, and the inspector should have good idea of possible failures and their consequences. This is important so that any observed anomaly can be tied down to its root cause, and that it may be subjected to further careful and intensive observation and follow up as would be needed. Generally, a list of the possible areas of concern may look like the one shown in Table 2. Such list is suggested only as a guide to possible events that can come about during the lifetime of the dam. It is the duty of the designer to include in his technical report of the dam all the assumptions used and the allowable limits of deviations compatible with safe performance; while the operation and maintenance report shall include best ways of carrying out visual inspections and monitoring of measurements, in addition to their frequency, details of the instruments used and the handling of the obtained data. The technical operating staff, in their turn, can upgrade this with the passage of time adding their experience with past occurrences and observed anomalies. 
Table 2: Check list for types of failures and their causes; to be used by inspection engineers.

\begin{tabular}{|c|c|c|}
\hline & Failure & $\begin{array}{c}\text { Cause } \\
\text { Can }\end{array}$ \\
\hline \multirow{2}{*}{1} & \multirow{2}{*}{$\begin{array}{l}\text { Foundation } \\
\text { Deterioration }\end{array}$} & Removal of Solids and Soluble Rock Plucking \\
\hline & & Under cutting \\
\hline \multirow{4}{*}{2} & \multirow{4}{*}{$\begin{array}{l}\text { Foundation } \\
\text { instability }\end{array}$} & Liquefaction \\
\hline & & Slides \\
\hline & & Subsidence \\
\hline & & Fault movement \\
\hline \multirow{4}{*}{3} & \multirow{4}{*}{$\begin{array}{l}\text { Defective } \\
\text { spillway }\end{array}$} & Obstructions \\
\hline & & Broken lining \\
\hline & & Evidence of overtaxing available capacity \\
\hline & & Faulty gates and hoists \\
\hline \multirow{4}{*}{4} & \multirow{4}{*}{$\begin{array}{l}\text { Defective } \\
\text { outlets }\end{array}$} & Obstructions \\
\hline & & Silt accumulations \\
\hline & & Faulty gates and hoists \\
\hline & & Gate position and location \\
\hline \multirow{3}{*}{5} & \multirow{3}{*}{$\begin{array}{c}\text { Concrete } \\
\text { deterioration }\end{array}$} & Alkali- aggregate reaction and sulfate attack \\
\hline & & Freezing and thawing \\
\hline & & Leaching of cement \\
\hline \multirow{4}{*}{6} & \multirow{4}{*}{$\begin{array}{l}\text { Concrete dam } \\
\text { defects }\end{array}$} & High uplift \\
\hline & & Unanticipated uplift distribution \\
\hline & & $\begin{array}{c}\text { Differential settlement } \\
\text { Differential displacements and deflections }\end{array}$ \\
\hline & & Overstressing \\
\hline \multirow{5}{*}{7} & \multirow{5}{*}{$\begin{array}{c}\text { Embankment } \\
\text { dam defects }\end{array}$} & Liquefaction potential \\
\hline & & Slope instability \\
\hline & & Excessive leakage \\
\hline & & Removal of solids and soluble materials \\
\hline & & Slope erosion \\
\hline \multirow{3}{*}{8} & \multirow{3}{*}{$\begin{array}{l}\text { Reservoir } \\
\text { margin defects }\end{array}$} & Perviousness \\
\hline & & Instability \\
\hline & & Inherent weakness of natural barrier \\
\hline
\end{tabular}

\subsection{Inspection of the Dam Body and Foundation}

In this inspection, it is always good practice that the inspection engineer gets familiarized with the design of the dams and the assumptions and data used by the designer before commencing any inspection round. It is advantageous also to see if the structural analysis of the dam is satisfactory or maybe, there is room for improvement if updated methods of analysis were to be used. A model check list of points to follow in such inspection is presented in Table 3. 
Table 3: Model check list for dam body and foundation inspections.

\begin{tabular}{|c|c|c|c|c|}
\hline & Location & Dam Type & Point for Observation & Remarks \\
\hline 1 & $\begin{array}{l}\text { Dam body } \\
\text { and } \\
\text { Foundation }\end{array}$ & $\begin{array}{l}\text { Earthfill } \\
\text { Rockfill } \\
\text { Concrete } \\
\text { Masonry } \\
\text { RCC }\end{array}$ & $\begin{array}{l}\text { Is leakage of water excessive? } \\
\text { Is it increasing or decreasing? } \\
\text { Is it clear or turbid? Are there } \\
\text { large variations in individual } \\
\text { drain discharges? Is } \\
\text { potentially dangerous seepage } \\
\text { apparent in the vicinity from } \\
\text { sources other than the } \\
\text { reservoir, such as in the } \\
\text { abutments at high level? }\end{array}$ & $\begin{array}{c}\text { Measurement of } \\
\text { seepage water quantity } \\
\text { are made by use of } \\
\text { weirs or flumes. } \\
\text { Quality of seepage } \\
\text { water is checked by } \\
\text { chemical analysis (See } \\
\text { also Points; } 2,3,5,6,7)\end{array}$ \\
\hline 2 & Dam body & $\begin{array}{l}\text { Earthfill } \\
\text { Rockfill }\end{array}$ & $\begin{array}{c}\text { Is piping evident, especially } \\
\text { where fills have been placed } \\
\text { against or } \\
\text { covered by structures? }\end{array}$ & $\begin{array}{c}\text { Appearance of turbid } \\
\text { water and/or boils are } \\
\text { signs of internal erosion } \\
\text { or suffusion }\end{array}$ \\
\hline 3 & Foundation & $\begin{array}{l}\text { Earthfill } \\
\text { Rockfill } \\
\text { Concrete } \\
\text { Masonry } \\
\text { RCC }\end{array}$ & $\begin{array}{l}\text { Are uplift pressures within the } \\
\text { design assumptions, or is it } \\
\text { necessary } \\
\text { to drill more relief holes into } \\
\text { the foundation. }\end{array}$ & $\begin{array}{c}\text { Such thing may appear } \\
\text { from observation of } \\
\text { piezometers }\end{array}$ \\
\hline 4 & $\begin{array}{c}\text { Concrete } \\
\text { facing slabs }\end{array}$ & $\begin{array}{l}\text { Earthfill } \\
\text { Rockfill } \\
\text { RCC }\end{array}$ & $\begin{array}{c}\text { Is there visible warping or } \\
\text { other distress? }\end{array}$ & $\begin{array}{c}\text { This can indicate } \\
\text { differential settlement } \\
\text { in dam body }\end{array}$ \\
\hline 5 & $\begin{array}{l}\text { Dam body } \\
\text { and } \\
\text { Foundations }\end{array}$ & $\begin{array}{l}\text { Earthfill } \\
\text { Rockfill }\end{array}$ & $\begin{array}{c}\text { Are there any signs of erosion } \\
\text { of the embankment or its } \\
\text { foundation? }\end{array}$ & $\begin{array}{l}\text { Has cracking developed } \\
\text { in structures, } \\
\text { embankments, or } \\
\text { foundations? }\end{array}$ \\
\hline 66 & Dam body & $\begin{array}{l}\text { Earthfill } \\
\text { Rockfill } \\
\text { Concrete } \\
\text { Masonry } \\
\text { RCC } \\
\end{array}$ & $\begin{array}{l}\text { Has cracking developed in } \\
\text { structures, embankments, or } \\
\text { foundations? }\end{array}$ & $\begin{array}{l}\text { These have to be } \\
\text { studies to see the } \\
\text { originating cause }\end{array}$ \\
\hline 7 & Foundations & $\begin{array}{l}\text { Earthfill } \\
\text { Rockfill } \\
\text { Concrete } \\
\text { Masonry } \\
\text { RCC } \\
\end{array}$ & $\begin{array}{l}\text { Is there evidence of chemical } \\
\text { alteration of foundation } \\
\text { materials? } \\
\text { Is there evidence of dissolution } \\
\text { of foundation rock by seepage? }\end{array}$ & $\begin{array}{c}\text { Testing of seepage } \\
\text { water samples takes } \\
\text { special importance for } \\
\text { dams of karstic nature }\end{array}$ \\
\hline
\end{tabular}




\subsection{Inspection of Appurtenant Structures Performance}

In this part of inspection and checking procedures, the inspection engineer has to go back, as a first step, to the original or updated rating curves of reservoir, spillway(s) and other outlet works to satisfy himself on the conformity of these curves with the actual work of these structures to avoid any unpleasant surprise specially during floods. Visual inspections proving that the structures performance is not impeded by sediments and debris have to be carried out. But, one suggested list of points to be observed in a detailed inspection may look like, but not limited to, the list shown in Table 4. Such list may be modified by an experienced dam safety reviewing engineer case by case depending on the actual situation. 
Table 4: Model Checklist for Appurtenant Structures Performance.

\begin{tabular}{|c|c|c|c|c|}
\hline No. & Structure & $\begin{array}{l}\text { Dam } \\
\text { Type }\end{array}$ & Point for Observation & Remarks \\
\hline 1 & Intake channels & All & $\begin{array}{l}\text { Is the inlet channel free } \\
\text { from obstructions and } \\
\text { does not cause heading } \\
\text { up of reservoir water } \\
\text { level? }\end{array}$ & $\begin{array}{l}\text { Heading up can } \\
\text { encroach on the free } \\
\text { board causing } \\
\text { overtopping. }\end{array}$ \\
\hline 2 & Spillway/ Outlet & All & $\begin{array}{l}\text { Is the spillway/ outlet } \\
\text { capacity adequate to } \\
\text { lower the reservoir } \\
\text { rapidly during an } \\
\text { emergency? }\end{array}$ & $\begin{array}{l}\text { Reference shall be } \\
\text { made to the rating } \\
\text { curves. }\end{array}$ \\
\hline 3 & Spillway/ Outlets & All & $\begin{array}{l}\text { Is the spillway intake } \\
\text { capable of passing flood } \\
\text { flows projected on the } \\
\text { basis of up to date } \\
\text { hydrological records? }\end{array}$ & $\begin{array}{l}\text { Reference shall be } \\
\text { made to the rating } \\
\text { curves and updated } \\
\text { hydrological study. }\end{array}$ \\
\hline 4 & Spillway chute & All & $\begin{array}{l}\text { Is the spillway chute in } \\
\text { good working } \\
\text { conditions and free } \\
\text { from blemishes that can } \\
\text { cause cavitation in } \\
\text { conditions of fast } \\
\text { flowing flows? }\end{array}$ & $\begin{array}{c}\text { Visual inspection can } \\
\text { prove this or } \\
\text { otherwise. }\end{array}$ \\
\hline 5 & $\begin{array}{l}\text { Stilling basins and } \\
\text { stilling pools }\end{array}$ & All & $\begin{array}{c}\text { Is there danger of } \\
\text { spillway discharge } \\
\text { undercutting the stilling } \\
\text { basin structure or } \\
\text { stilling pool? }\end{array}$ & $\begin{array}{c}\text { Visual inspection can } \\
\text { prove this or } \\
\text { otherwise. }\end{array}$ \\
\hline 6 & $\begin{array}{c}\text { Intake of outlets } \\
\text { works and Spillway } \\
\text { Intake }\end{array}$ & All & $\begin{array}{c}\text { Are intake works for } \\
\text { outlets and spillways } \\
\text { free from silt and } \\
\text { debris? }\end{array}$ & $\begin{array}{l}\text { Visual inspection can } \\
\text { prove this or } \\
\text { otherwise. }\end{array}$ \\
\hline 7 & $\begin{array}{l}\text { Discharge outlet } \\
\text { Channel }\end{array}$ & All & $\begin{array}{l}\text { Is the downstream } \\
\text { outlet channel } \\
\text { constructed and } \\
\text { maintained so that } \\
\text { there will be no } \\
\text { dangerous erosion, or } \\
\text { debris deposited, in the } \\
\text { river channel? } \\
\end{array}$ & $\begin{array}{l}\text { Decided from } \\
\text { experience of channel } \\
\text { performance and } \\
\text { visual inspection. }\end{array}$ \\
\hline
\end{tabular}




\subsection{Special Points to be observed for Concrete Dams Inspections}

In addition to points of interest for the inspecting engineer already mentioned in Tables 2 and 3, there are other special points concerning concrete dams and should not escape either his attention or his careful documenting. In concrete dams, examination of concrete strength is an important parameter to be checked, especially in older dams. In freezing climate, additional thrust of ice sheets, over and above, the assumed thrust has to be reconsidered.

Carrying out nondestructive tests may reveal reduction of concrete strength, therefore, testing by extracting cores to confirm the integrity of the dam has to be conducted.

Among other checking, deterioration of concrete quality can result from the reaction of alkali- reactive concrete constituents with water over long time or from sulfate attack of the sulphates in cement and sand originally used for construction. Cracking or spalling will follow such reactions, but they may take some time to show their impacts. So, they are more characteristic of older dams. The final outcome is marked by reduction of concrete quality and strength which qualifies for effective upgrading measures to insure their safety. Alkali reaction and sulfate attack are among the most serious sources of undermining for concrete dams' safety to be attended to in rehabilitation programs of dams.

Other issues which can undermine dams' stability and integrity are opening up of joints between concrete lifts which means the performance of the dam as one unit no longer exists. The progress of joint opening shall be followed carefully and continuously and if seepage water starts to appear in these joints, then this indicates the development of dangerous uplift which represents another source of worry, and similarly may lead to leaching of cement and cause its crumbling. Freezing and thawing in extreme weather condition exasperate the process and lead to the progress of opening up of these joints.

Concrete surfaces subject to flow of water wear with time, especially in parts of high velocity flow in spillways and outlet structures. This wearing processes is exasperated by heavy sediment loads and debris carried by the flowing water during high floods.

The inspection engineer has to look further for indications of any cavitation problems which develop with time due roughened concrete surfaces or missalignments of planes in conduits, chutes, and stilling basins.

The question of workable drains and uplift pressure relief wells is important for the general stability of the dam. These devices which ensure dam's stability against sliding and overturning tend to be clogged during the passage of time by soil particles or salts depositions such as chlorides or sulphates.

Any meaningful rehabilitation program of concrete dams aiming at reducing its hazards has to be based on sound and careful review of inspections and testing results. Case histories of similar damages, inspection rounds and upgrading rehabilitation programs are given in a paper by the authors under the title of "Dams Safety and problems in Aging Dams" which is in the print [5]. 


\subsection{Inspection of Systems and Metal Equipment}

General but essential items involving systems and metal parts have to be checked on the onset of any safety inspection of dam before going into the next detailed procedures. These general items are summarized in Table 5.

Table 5: General Issues of Safety Requirements for installed systems.

\begin{tabular}{|c|c|c|c|}
\hline No. & Item & Points for Observation & Remarks \\
\hline 1 & Auxiliary Power Supply & $\begin{array}{l}\text { Is it available and in } \\
\text { standby operating } \\
\text { readiness? }\end{array}$ & $\begin{array}{c}\text { This covers } \\
\text { generators and } \\
\text { connecting cables, } \\
\text { switches, and } \\
\text { controls. }\end{array}$ \\
\hline 2 & $\begin{array}{l}\text { Systems availability for } \\
\text { manual operation of } \\
\text { hoists and servomotors }\end{array}$ & $\begin{array}{l}\text { Oil filled cylinders and } \\
\text { their state of readiness. }\end{array}$ & $\begin{array}{l}\text { These equipment are } \\
\text { essential for } \\
\text { controlling out flow } \\
\text { and need constant } \\
\text { attention. }\end{array}$ \\
\hline 3 & $\begin{array}{c}\text { Adequacy and reliability } \\
\text { of ventilation system } \\
\text { provided in shafts, } \\
\text { tunnels, and galleries }\end{array}$ & $\begin{array}{l}\text { Working readiness and } \\
\text { reliability. }\end{array}$ & $\begin{array}{l}\text { To prevent corrosion } \\
\text { and to protect } \\
\text { personnel from } \\
\text { noxious gases. }\end{array}$ \\
\hline 4 & $\begin{array}{c}\text { Gates, Valves, Hoists and } \\
\text { Servomotors and other } \\
\text { essential operation } \\
\text { equipment }\end{array}$ & $\begin{array}{l}\text { Are they in operable } \\
\text { conditions? }\end{array}$ & $\begin{array}{c}\text { Frequent checks are } \\
\text { necessary. }\end{array}$ \\
\hline 5 & Drainage sump pumps & $\begin{array}{l}\text { Are they in operable } \\
\text { conditions? }\end{array}$ & $\begin{array}{c}\text { Frequent checks are } \\
\text { necessary }\end{array}$ \\
\hline 6 & $\begin{array}{l}\text { Automatic alarms and } \\
\text { Telemetering devices }\end{array}$ & $\begin{array}{l}\text { Are all properly } \\
\text { functioning? }\end{array}$ & $\begin{array}{c}\text { Constant Checking is } \\
\text { needed to avoid false } \\
\text { alarms or readings }\end{array}$ \\
\hline 7 & $\begin{array}{l}\text { Operating mechanisms } \\
\text { which do not need } \\
\text { frequent checking }\end{array}$ & $\begin{array}{l}\text { Their functioning still need } \\
\text { to be checked every now } \\
\text { and then. Such examples } \\
\text { are firefighting systems and } \\
\text { the like. }\end{array}$ & $\begin{array}{l}\text { To ensure working } \\
\text { condition when } \\
\text { needed. }\end{array}$ \\
\hline 8 & $\begin{array}{l}\text { Emergency supplies and } \\
\text { spare parts and tools }\end{array}$ & $\begin{array}{c}\text { An inventory of these items } \\
\text { shall be kept ready for use } \\
\text { and shall be updated from } \\
\text { time to times. }\end{array}$ & $\begin{array}{l}\text { Such supplies and } \\
\text { tools help taking fast } \\
\text { actions during } \\
\text { emergencies. }\end{array}$ \\
\hline
\end{tabular}


The detailed inspection of the spillway and outlets metal works and piping systems is an important aspect for insuring safe operation, therefore, they deserve special attention in the safety inspection routines. Such inspection should be followed by corrective actions in case of discovering deficiencies.

Common areas of problems which should not escape the attention of the experienced inspecting engineers may be outlines in the following:

\section{Corrosion and Rusting, and Use of Galvanic Action}

Corrosion is progressive deterioration resulting from exposure to moisture, acid, and other corrosive agents, and usually is marked by scaling or flaking, pitting, and color changes. Loss of paint or other protective coatings can leave a metal surface subject to corrosion, especially if the surface is cycled between wet and dry condition. Unchecked corrosion eventually leads to failure of a metal structure.

In the protection of metals such as those used in control equipment of gated spillways and outlets structures or protective trash screens and piping systems, cathodic protection may prove to be necessary. By installation of these systems, a galvanic anode, a piece of a more electrochemically "active" metal is attached to the vulnerable metal surface exposed to an electrolyte. Galvanic anodes are selected because they have a more "active" voltage than the metal of the target structure which are typically steel. Normally, anodes consist of such metal pieces or bands like Zinc or Magnesium attached to the metallic part needing protection. The inspector has to make sure of locating and examining all accessible anodes installed for cathodic protection of the metal parts under consideration. An anode may need replacement if it is excessively corroded.

\section{Fatigue and Cracking}

Fatigue is loss of metal strength from repetitive loading, such as being bent back and forth. Protrusions on metal components or components with moving parts are most likely to suffer fatigue. Cracking is usually induced by vibrations and fluctuating dynamic loadings common in hydraulic structures. Distortions or cracked paint or damaged welding seem may indicate locations where a metal structure suffers from fatigue. The deterioration continues until the affected area cracks and/or breaks. Visual observation of such distortions and loss of paint or distorted welding seem should not escape the attention of a good inspector nor the appreciation of its consequences. One step further to such inspection and discovery of such defect may be taken by applying appropriate nondestructive tests in order to reach decision on the best possible repair action or may be the replacement of the defective part.

\section{Erosion, Tearing and Rupture}

Flow surfaces and areas around rivets and splice plates may be scoured by abrasive debris. These items may not be too difficult to replace when are discovered by the observant eye of practicing inspector. Discovering such issues and treating them in time could save much trouble later if they escaped notice or being ignored. Tearing 
and rupture may result from impact of large debris such as a logs slamming into a steel lining. In spillways, metal components are most likely to tear and rupture during storms or other occasions when the flow is heavily loaded with sediments and debris. Tears and ruptures can cause a metal structure to fail completely, or expose the structure to corrosion, cavitation, fatigue, or other damage(s).

\section{Cavitation}

Cavitation of metal surfaces, such as metal conduits, can occur when high flow velocities exist on flow surface with offsets and irregularities. The bubble collapse dynamics of cavitation cause pitting of the surface, which leads into progressive deterioration to the damaged area. As in concrete, the site of initial cavitation damage triggers the formation of another site downstream, so the process develops in a leapfrog pattern. Areas just downstream of gates and valves are susceptible to this phenomenon also $[6,7]$.Timely discovery of cavitation by careful inspection can save a great deal of cost and repairs effort in selecting and applying the corrective measure(s).

\subsection{Program of Inspections and Reports of Findings}

To maintain control of the inspection program, an inspection schedule should be maintained which lists each feature to be inspected, frequency of inspections, date of last inspection, maintenance record, description of repairs made, and date of next inspection. The schedule should also have a note on major alterations that are made. Inspection personnel should be selected carefully; should have qualifications commensurate with their assigned levels of responsibility and have received training in inspection procedures. Qualifications and training required for inspection personnel may vary with the complexity of the facility and with the level of inspection.

Upon completion of an inspection round of a dam, the inspector' team should formulate and report its findings in the Inspection Report.

When serious dam safety issue is encountered then this must be brought up immediately to the attention of the dam management for further action.

This report serves also as a follow up of previous inspections and should have answers to whether all previous adverse or questionable conditions have been taken care of, and if deficiencies been remedied without delay. The question whether the operation personnel have proper instructions and authority for actions to be taken during an emergency shall be addressed.

A good report has to contain a follow up of developments such as variations in seepage water quantities and piezometric measurements related to changes in the reservoir water levels. The report shall, therefore, contain summary of such measurements and recordings taken during the time period since the last inspection added to those produced in the previous report. Presentation of such measurements shall be in tabular and/or graphical form with appropriate comments on them.

If an emergency had occurred during the period between inspections, whether in 
passing exceptional flood or an earthquake event, detailed reports on these incidents shall be attached as appendices, even if such reports were prepared by other specialized teams or agencies who, without any doubt, have included observations, descriptions and evaluations of damages that were sustained by the dam and its structures, if any.

All noteworthy observations should be documented by photographs, videos, and illustrations with sufficient details of dates and comments. Finally, the report shall evaluate the adequacy, or otherwise, of periods between inspections and if more frequent inspections are needed in light of dam safety status.

\subsection{General Types and Frequencies of Inspections and safety Reviews}

Types and frequency of dam safety inspections vary from country to country, but generally they follow general agreed principles which take into consideration type of dam, its age, and the risks it presents to population and infrastructures.

Inspection types and their frequencies included in an inspection program for any dam should not preclude other inspections or more frequent inspections, if deemed necessary depending on dam history and importance of the facility. For some projects, less frequent inspections may be permissible where hazard potential and structural integrity warrant such relaxation.

A model procedure for carrying out inspections and their types are presented in the following:

\section{Informal inspections and their frequency}

Informal inspections are normally assigned to onsite operating personnel who have direct responsibility of the smooth operation of the dam and follow up of its good conditions. Those operators need not have formal education in the fields of engineering or geology, but they should be well trained and made aware of the heavy reliance placed upon them and the great importance and absolute necessity of their careful inspection and reporting.

They are to identify and report the various aspects of dam behavior in accordance with detailed instructions and checklist of items needing inspection.

This list should be prepared specifically for the project by engineering and operating specialists and should give adequate instructions and guidance.

Any unusual conditions that seem critical or dangerous and needs immediate attention should be reported promptly to the higher level of management or to those assigned the inspection responsibility. Particular attention should be given to detecting evidence of (or changes in) leakage, erosion, sinkholes, boils, seepage, slope instability, undue settlement, displacement, tilting, cracking, deterioration, and improper functioning of drains and relief wells, as outlined in previous paragraphs.

Informal inspections should be scheduled as needed according to the dam's size, importance, and potential for loss of life and damage to property. The schedule for inspection should be changed by the engineers as required to be responsive to observed changing conditions. But the operating personnel are expected to perform 
an inspection immediately after any unusual event such as large floods, earthquakes, suspected sabotage, or vandalism. In such cases they may need to take photographs and/or videos to give real time recordings of such incidents.

\section{Intermediate Inspections and their frequency}

Intermediate inspections should include a thorough field inspection of the dam and appurtenant structures, and a review of the records of inspections made at and following the last formal inspection. If unusual conditions are observed that are outside the expertise of those inspectors, arrangements should be made for inspections to be conducted by specialists.

Intermediate inspections frequency is normally specified in various country dam safety codes and guidelines, but preferably performed on an annual basis, or at least biannually, especially where there is a high probability that dam failure could result in loss of life. For other dams, intermediate inspections should be scheduled by responsible engineers on the basis of the dam's size, importance, and potential for damage to life and property.

Intermediate inspections should be performed by technically qualified engineers, experienced in the operation and maintenance of dams, and trained to recognize abnormal conditions. The inspectors should have access to and, be familiar with, all permanent documentation, especially the operation and maintenance histories for the dam and should be responsible for, and intimately familiar with, the operating characteristics of the dam. The dam operators should be participants in these inspections.

\section{Formal and Special Inspections}

A formal inspection is required periodically to verify the safety and integrity of the dam and appurtenant structures. Formal inspections should include a safety review to determine if the structures meet current accepted design criteria and practices. It shall also involve review of all related documents including instrumentation records, operation, and maintenance procedures and, to the degree necessary, documentation on investigation, design, and construction.

In performing the detailed inspection of the dam appurtenant structures and equipment, diving inspections of underwater structures affecting the integrity of the dam may have to be included. All formal inspections should be conducted by a team of highly specialized and trained engineers and geologists. To assure that a dam and its appurtenant facilities are thoroughly inspected, checklists should be prepared to cover the condition of foundations, structural, electrical, and mechanical features. Such inspection should also verify that operating instructions are available and fully understood. To answer whether instrumentation system is adequate and data is assessed to assure structures are performing as designed, and if there are emergency provisions for accessing to and communication with all project operating facilities. Formal inspections should be made periodically at intervals not to exceeding five years. Depending on past experience or the project history, some dams may require more frequent formal inspections. Out of the adopted inspection schedule, special 
inspections should be performed immediately after the dam has passed unusually large floods and after the occurrence of significant earthquakes, sabotage, or other unusual events reported by the operating personnel.

Formal and special inspections are being conducted under the direction of licensed professional engineers experienced in the investigation, design, construction, and operation of dams. The inspection team should be chosen on a site-specific basis considering the nature and type of the dam. The inspection team should comprise individuals having appropriate specialized knowledge in; structural, mechanical, electrical, hydraulic, and embankment design, geology, concrete materials, and construction procedures. They should be capable of interpreting structural performance and relating conditions found to current criteria and safety aspects. It is imperative that the inspection team adequately prepare for the inspections by reviewing and discussing all documents relating to the safety of the dam [8].

\section{Instrumentation Monitoring and Surveillance}

As supplement to field inspections, instruments' observations and recordings can give better insight to dam's behavior; together with the inspections they also provide sound basis for dam safety reviews. Instrumentation to monitor structural and functional performance are therefore necessary.

Careful examination of instrumentation data on a continuing basis may reveal a possible critical condition. Conversely, instrumentation may be means of assuring that an observed condition is not serious and does not require immediate remedial measures.

Design and installation of instruments are usually done during design and implementation phases. The number of instruments, their types and their layout are decided by many factors, among these; the importance and size of the dam, the magnitude of risks it poses to population and infrastructures in the downstream reach in addition to complexity of the site.

The types of instruments needed in typical important dam, depending on type of dam whether concrete or embankment dam, may include combination of any of the following devices:

- Piezometers

- upstream and downstream water level gauges,

- horizontal and vertical alignment instrumentation (Concrete Structures), geodetic survey beacons,

- inclinometers,

- inverted plumb bobs,

- extensometers

- total earth pressure cells and pore-water pressure cells (Embankment Structures),

- settlement plates,

- seismic instrumentation, 
- Seepage water quantities measuring devices such as Weirs and Parshall flumes are needed and frequent sampling and testing for soluble salts concentrations may be required in many special cases where dams are located in karst areas or built on soluble foundation rock.

Instruments should be examined periodically for proper functioning, and the adequacy of the installed instruments are to be assessed from time to time by specialists to determine if they are sufficient for evaluating the performance of the dam. An experienced inspector may find gaps in important data which have to be filled by more of the same instrument or by another type of instrument. If for example seismic instrumentations are not installed in a dam, the need for such instruments becomes evident after an earthquake event.

Inspection of the installed instruments' status and their working condition is the duty of the dam operation personnel, while final evaluation of the devices' conditions, quality of data obtained and need for more of them is the duty of an instrumentation expert working with the formal inspection team. Questions such as, but not limited to those, are given in Table 6 have to be answered. 
Table 6: Points to be observed in instrumentation control work.

\begin{tabular}{|c|c|c|c|}
\hline & Item & Point of observation & Remarks \\
\hline 1 & $\begin{array}{l}\text { U/s and D/s water } \\
\text { levels gauges }\end{array}$ & $\begin{array}{l}\text { General working } \\
\text { conditions }\end{array}$ & $\begin{array}{l}\text { Are there any obstructions such } \\
\text { as weed, debris or others }\end{array}$ \\
\hline 2 & $\begin{array}{l}\text { Stand pipe } \\
\text { piezometers }\end{array}$ & $\begin{array}{l}\text { General appearance } \\
\text { and checking for any } \\
\text { erratic reading }\end{array}$ & $\begin{array}{c}\text { Can be damaged by external } \\
\text { agents, or have clogged filters. In } \\
\text { piezometers acting under } \\
\text { hydrostatic conditions, pressure } \\
\text { manometers have to be checked, } \\
\text { recalibrated, or replaced } \\
\end{array}$ \\
\hline 3 & Relief wells & $\begin{array}{l}\text { General appearance } \\
\text { and quality of drainage } \\
\text { water }\end{array}$ & $\begin{array}{l}\text { Is drainage water turbid or } \\
\text { discolored? Do chemical testing } \\
\text { results indicate increase in } \\
\text { soluble salts concentrations? }\end{array}$ \\
\hline 4 & $\begin{array}{c}\text { Settlement and } \\
\text { alignments, } \\
\text { horizontal and } \\
\text { vertical } \\
\text { displacement devices }\end{array}$ & $\begin{array}{l}\text { Is there any out of } \\
\text { normal movement in } \\
\text { dam body and } \\
\text { appurtenant }\end{array}$ & $\begin{array}{l}\text { If measured values are out of } \\
\text { calculated safe values, do these } \\
\text { merit special in-depth analysis? }\end{array}$ \\
\hline 5 & $\begin{array}{l}\text { Performance and } \\
\text { presentation of } \\
\text { measurements and } \\
\text { recordings }\end{array}$ & $\begin{array}{l}\text { Are competent, trained } \\
\text { personnel assigned to } \\
\text { surveillance? }\end{array}$ & $\begin{array}{l}\text { Is performance of this work done } \\
\text { according to approved check list? } \\
\text { Does the quality of presentation } \\
\text { allows good interpretation }\end{array}$ \\
\hline 6 & $\begin{array}{l}\text { Timing of } \\
\text { observations and } \\
\text { reporting }\end{array}$ & $\begin{array}{l}\text { Does the frequency of } \\
\text { readings conform with } \\
\text { safety appraisal } \\
\text { requirements? Is } \\
\text { reporting done in time? }\end{array}$ & $\begin{array}{c}\text { Observation frequency is } \\
\text { established by a specialists and } \\
\text { may deviate in case of unforeseen } \\
\text { emergencies as decided by well- } \\
\text { trained operators. Reporting in } \\
\text { time facilitates early safety } \\
\text { review } \\
\end{array}$ \\
\hline 7 & $\begin{array}{c}\text { Adequacy of } \\
\text { installed instrument } \\
\text { devices. }\end{array}$ & $\begin{array}{l}\text { Numbers and types } \\
\text { Quantity and quality of } \\
\text { obtained data. }\end{array}$ & $\begin{array}{l}\text { Is the retrieved data enough to } \\
\text { ascertain the safe condition of the } \\
\text { dam? }\end{array}$ \\
\hline
\end{tabular}

The instrumentation data should be collected by personnel trained specifically for this purpose. Such training should include training to recognize and report immediately anomalies in the readings or measurements. Performance observation data should be properly tabulated for easy interpretation and may be supported by comments, diagrams, and curves.

The frequency of instruments' readings should be established at the time of design of the dam; when the instrumentation system itself is designed. Such frequency is established to give a timely warning of possible adverse conditions. But, whenever 
necessary, more frequent readings, sometimes as often as hourly, should be done to monitor a suspected rapidly changing adverse condition. The frequency or number of readings may be reduced after the project has been in operation for an extended time and performance observation data indicates that readings have stabilized.

It is essential that instrumentation data be processed, reviewed, and assessed in a timely manner by specialists familiar with the design, construction, and operation of the project. Operation manuals and design information should be referred to in the evaluation of possible adverse trends. The performance observation data should be periodically analyzed to determine whether project structures are reacting as assumed in the design, and to detect deviation if any.

Many dam regulating authorities; such as governments or other public authorities have laid out guidelines and procedures for carrying out inspections and safety reviews of dams under their jurisdiction to ensure their proper performance and reducing risks to the public.

Examples are given in references such as those listed in the references list under numbers $[4,8,9,10,11,12]$.

\section{Guidelines, Rules and Legislations for Dam Safety Reviews}

Generally, rules for inspection, safety review and legislations in various countries may have taken different routes of development in different countries, but such development has been guided and dictated more often from experiencing failures and incidents in these countries together with lessons derived from other countries experiences. Most countries owning dams have promulgated laws and acts regulating these issues, such as UK, USA, France, Canada, India, Australia, Sweden, and others. In the following paragraphs, only the first four mentioned countries are considered which exemplify similar methods and procedures in all other countries.

\subsection{Dam Safety Guidelines and Legislations in UK}

Dam safety Management in the UK is governed generally by legislations whereby responsibility is divided between dam owners, councils or local governments, government departments and technical panels of qualified engineers appointed by the Institute of Civil Engineers (ICE). Promulgation of legislations leading to prescribing procedures for dam safety control was done for the first time in 1925. It was driven by the failure of two dams in this year which caused a flood that swamped the village of Dolgarrog in North Wales, killing 16 people.

The disaster began by the failure of the Eigiau Dam, a small gravity dam. The water released from the reservoir flooded downstream, and overtopped the Coedty Dam, an embankment dam. This dam failed, releasing the huge volume of water that flooded Dolgarrog. The disaster at Dolgarrog led the British parliament to pass the Reservoirs- Safety Provisions Act in 1930 that introduced laws on the safety of reservoirs. This has since been updated; the current legislation is:

i. in England and Wales: Reservoirs Act, 1975

ii. in Scotland: Reservoirs-Scotland Act, 2011

iii. in Northern Ireland: Reservoirs-Northern Ireland Act, 2015 
These Acts cover the safety reviews of all reservoirs in the United Kingdom that can hold at least 10,000 or $25,000 \mathrm{~m}^{3}$ of water, depending on location (currently the $10,000 \mathrm{~m}^{3}$ lower limit only applies in Wales).

Under these Acts, there are "Panels" (or groups) of civil engineers who are responsible for checking the safety of these reservoirs and their dams. They are called "Panel Engineers", and they can only belong to the Panels if they are considered to be professionally qualified, and experienced in reservoir safety matters. Every reservoir has to be safety reviewed every 10 years, or more often, when it is necessary. Panel Engineers also get involved with the construction of new reservoirs and repairs and changes to existing ones [13].

Annual safety inspections are left to a supervising engineer who is required with his team to supervise the operation and maintenance of the reservoir and produce an annual statement summarizing the performance of the reservoir over the previous year. A Supervising Engineer's team must be available "at all times". They can require maintenance works to be carried out and can also recommend that specialist engineers carry out an early inspection if they have sufficient concerns.

Although the "Supervising Engineer" is responsible for advising the owner for any issues that might affect safety of the reservoir, they will only usually visit once or twice a year, and therefore rely on technicians and operational staff to spot early signs of a problem. These are usually recognized by routine daily or weekly inspections as deemed necessary through visible changes to the structure, or by recording and taking measurements. Having been previously well trained and informed of what can go wrong, the operating team has an essential role in helping to look out and discover any early signs of problems with particularly spotting signs of change. Such possible changes include but not limited to, movements, seepages, and other features putting the dam at risk, for example a blocked overflow [14].

\subsection{Dam Safety Guidelines and Legislations in the United States}

Dam safety legislations and inspection procedures in the United States have, so far, followed gradual development and were driven by series of catastrophic failures. History of dams in the United States is rich with failure cases which had caused tragic deaths and appreciable damages. Early examples are:

- Mill River Dam (1847), Massachusetts,140 people were killed.

- $\quad$ South Fork Dam (1889), Johnstown, Pennsylvania, 2,200 people were killed.

- St. Francis Dam (1928), California, 450 people were killed.

Many more failures in Arizona, Tennessee, Oregon, North Carolina, Texas, Virginia, West Virginia, and elsewhere across the U.S. occurred around the turn of the century, leading to the passage of some early state dam safety legislation.

The failure of St. Francis Dam, in March 1928, was a landmark event in the history of state's dam safety legislation, spurring legislation not only in California, but in neighboring states as well. However, most states had no substantive dam safety laws prior to a series of dam failures and incidents that occurred in the 1970s.

The conclusion that may be drawn from all these cases is that safety inspection procedures were not as rigorous as they should have been and in most cases this 
was left to the owners themselves, and there were no unified legislations governing this matter.

Major disasters of dam failures occurred in various countries during the 1960s such as at Malpasset- France on December 2, 1959, killing 423 people, Vajont- Italy on October 9, 1963, killing 2,000 people, and Baldwin Hills-USA on December 14, 1963, resulting in five deaths and the destruction of 277 homes, but without the vigorous rescue efforts much greater loss of life could have happened. These catastrophes instigated several countries to enact new or revise laws for supervision of safety of dams and reservoirs. The Dam Inspection Act, U.S. Congressional Public Law 92-367 signed into law on August 8, 1972, authorized the Secretary of the Army, acting through the Chief of Engineers, to undertake a national program of inspection of dams. Under this authority, the Corps of Engineers has:

i. compiled an inventory of Federal and non-Federal dams;

ii. conducted a survey of each State and Federal agency's capabilities, practices, and regulations regarding the design, construction, operation, and maintenance of dams;

iii. developed guidelines for safety inspections and evaluations of dams; and

iv. formulated recommendations for a comprehensive national dam safety program [1].

Following the failure of Kelly Barnes Dam, Toccoa Falls, Georgia, on November 6, 1977 killing 39 students and college staff and causing about $\$ 2.5$ million in damages, President Jimmy Carter directed the US Army Corps of Engineers to inspect the nation's non-federal high-hazard dams. This "Phase (I) Inspection Program" lasted from 1978-1981. The findings of the inspection program were responsible for the establishment of dam safety programs in most states, and, ultimately, the creation of the National Dam Safety Program, which supports dam safety programs in 49 states, all but Alabama, which has yet to pass dam safety legislation [15].

Resulting from the Program, inspections of dams and number of Emergency Action Plans (EAPs) for high-hazard potential dams has increased, and better tools and guidance for dam operation and maintenance have been developed. The work that has been done under this Program has played an important role in reducing the loss of life and damage to property and the environment from dam failures.

Further to this, the Dam Safety Act of 2006 - (33 U.S.C. $§ 467$ note)- required the (Administrator) of the Federal Emergency Management Agency (FEMA) to submit a biennial report on the National Dam Safety Program to Congress. The act required the report to include the status of the Program and the progress achieved by Federal agencies and participating states in implementing of the "Federal Guidelines for Dam Safety (FEMA, 2004)" [16].

In all this activity the USACE had carried out major dam inspections of approximately 700 dams nationwide that fall under its jurisdiction with the objectives of:

i. Ensure the dam system will perform as expected,

ii. Identify deficiencies or areas that need monitoring or immediate repair, 
iii. Continuously assess the integrity of the dam in order to identify any changes over time,

iv. Collect information in order to make informed decisions about future actions,

v. Determine if the dam is being properly operated and maintained.

Achieving these goals requires the United Army Corp of Engineers to conduct two types of dam inspections. The first one is the "Annual Inspection", which is performed on an annual basis to ensure the dam is being properly operated and maintained. The second one is "Periodic Inspection" which is the next level of inspection and is conducted by a multidisciplinary team led by a professional engineer. It includes a more detailed, comprehensive evaluation of the condition of the dam and will be conducted every five years. Components of the "Periodic Inspection" include evaluating annual inspection items; verifying proper operation and maintenance; evaluating operational adequacy, structural stability, and safety of the system; and comparing current design and construction criteria with those in place when the dam was built [17].

The United State Bureau of Reclamation in its turn has followed the "Safety of Dams Act" of 1978- Public Law 95-578, November 2, 1978- which provided the Bureau through the Secretary of the Interior with the authority to construct, restore, operate, and maintain new or modified features at existing Federal Reclamation dams for safety of dams purposes.

The Bureau of Reclamation is responsible for administering its 491 dams and takes care of wide range of activities which includes those related to the operation, maintenance, and safety reviews of these dams. The activities are:

i. Periodic onsite examinations;

ii. Following up dam behavior through observations and reporting;

iii. In depth studies of visually identified or suspected defects such as general deterioration, seepage, structural distress, spillway and outlet hydraulic behavior, and adjacent endangering geologic conditions;

iv. Comprehensive analytical studies to evaluate such items as spillway capacity, seismic stability, or surveillance instrumentation utilizing modern technology;

v. Maintaining of up to date "Standing Operating Procedures" for operation and maintenance of each dam and appurtenant structures;

vi. Awareness and reporting of hazardous conditions existing in upstream dams belonging to others that might adversely affect the safety of Bureau dams;

vii. Monitoring of potential landslide areas;

viii. Preparation of designs and supervision of construction for dam modification, and

ix. rehabilitation, or replacement for safety purposes [4].

\subsection{Dam Safety Guidelines and Legislations in France}

In France, the general rule is; protection of persons and property is a responsibility of the Government, who must legislate (create regulation) and enforce the rules through administrative bodies (agency, department, office,.. etc.) to provide for the 
safety and security of the people, property, and environment. That is why dam design, construction, rehabilitation, enlargement, alteration, operation, inspections, monitoring, maintenance, repair, breach, abandonment, and removal must rely on a legal frame that establishes rights, responsibilities and duties of the parties involved. Within this legal frame, three "ministries" have responsibility for dams. The Ministry of Transport; for structures associated with canals, the Ministry of Industry; for hydro and tailings dams, and the Ministry of Environment; for other dams.

The present regulation requires that safety concerns be addressed as early as the preconstruction stage. It is meant, as stipulated by the legislature, to cover dams and levees in a coherent manner, and the basic framework should be the same for all dams, regardless of whether they are for electricity production, water supply, irrigation, flood control or other purposes.

Requirements for dams' Inspections, safety reviews and control vary on the basis of dam and reservoir size. Size is based on criteria combining dam height $(\mathrm{H})$ and reservoir capacity $(\mathrm{V})$, being intuitively true that a small dam impounding a lot of water may be as much of a danger as a high dam impounding little water.

Recent changes in French regulation made in 2007 require adoption of new dam classification system, according to "Risk Prioritization Criteria" introducing a graded system with four classes of dams [18]:
A. $\mathrm{H} \geq 20 \mathrm{~m}$
B. $10<\mathrm{H}<20 \mathrm{~m}$ and $\mathrm{H}^{2} \sqrt{ } \mathrm{V} \geq 200\left(\mathrm{~V}\right.$ in ha $\left.{ }^{3}\right)$
C. $5<\mathrm{H}<10 \mathrm{~m}$ and $\mathrm{H}^{2} \sqrt{ } \mathrm{V} \geq 20$
D. $2<\mathrm{H}<5 \mathrm{~m}$,

Moreover, for each new dam with a height more than $20 \mathrm{~m}$ and/or the size of the reservoir is $15 \times 10^{6} \mathrm{~m}^{3}$, a technical file must be submitted by the owner to government authorities for approval and it should be subject to emergency planning regulations [19].

Inspections, safety reviews and repairs of old dams are normally overseen by a technical committee called the "Standing Committee", which is formed of members from the previously mentioned ministries and acts as the "Supervising Authority". The "Supervising Authority" is responsible for enforcing the "Regulation" and ensuring that the "Owner" complies with his responsibilities, this means that the staff in charge of the supervision must possess sufficient skills and knowledge to be able to judge if the "Owner's" efforts are commensurate to his duties.

Dams under construction are also subject to compulsory continuous safety surveys by the construction supervisor, who is also responsible for the safe first filling.

After end of construction, the "Owner" must do periodical visual inspections and monitoring at agreed frequencies and should report the findings of any anomaly or defect. All these are considered as the first line of defense. Comprehensive safety reviews should be carried out by the "Owner" yearly during the first five years from the date of commissioning followed by similar checks at five years and ten years' intervals. The dam owner is also responsible for preparing an Emergency Action 
Plan (EAP) to meet unforeseen emergencies but inundation maps in case of dam failure are prepared by the local authority of the county in which the dam is located. Initially the "Supervising Authority" and the "Owner" should conduct an inventory of dams to determine:

a. name and address of the owner;

b. the location, type, size, purpose, and height of the dam;

c. storage capacity;

d. as accurately as may be readily obtained, the area of the drainage basin, rainfall and stream flow records, flood-flow records, and estimates;

e. classification of the dam according to the hazard potential risk.

Based on this inventory, the "Supervising Authority" shall first classify the dams according to their risk (potential and present) and even identify the small dams with a high risk accordingly to the Risk Prioritization Criteria into classes of A, B, C, or $\mathrm{D}$; as figured already, and then performs safety reviews of these dams. The regional supervisors shall have the support of teams of specialists (engineers with experience in civil, geotechnical, hydraulic, hydrological and risk engineering), and whenever, the "Supervising Authority" finds that any owner has violated a provision of the "Regulation" it may do the following:

i. issue an administrative order requiring any such owner or company to comply with his/hers/its duties,

ii. bring a civil action against the violator,

iii. levy a civil administrative penalty (fine),

iv. petition the Attorney General (or its equivalent) to bring a criminal action.

The use or application of any of these remedies shall not preclude recourse to any of the other remedies prescribed.

The "Supervising Authority" also shall have the power to adopt rules, standards and requirements for the design, construction, reconstruction, enlargement, alteration, operation, monitoring, maintenance, modification, repair, breach, abandonment and removal of dams and reservoirs to carry out the purpose of the Regulation. To exemplify some of the responsibilities of the "Supervisory Authority" in practical terms, Table 7 presents the duties of this body in France regarding the four classes of dams [18]. Further to this, the duties of dam owners as defined by the present French legislation are based on the same dams' types classification and summarized in Table 8 [18]. 
Table 7: Duties of the "Supervisory Authority" according the French dam type's classification.

\begin{tabular}{|c|c|c|c|c|}
\hline Duties & A & B & C & D \\
\hline $\begin{array}{c}\text { Technical and } \\
\text { administrative approval }\end{array}$ & yes & yes & yes & yes \\
\hline $\begin{array}{c}\text { Attendance at foundation } \\
\text { excavation acceptance } \\
\text { inspection }\end{array}$ & recommended & recommended & possible & no \\
\hline $\begin{array}{c}\text { Inspection of completed } \\
\text { scheme and verification of } \\
\text { conformity }\end{array}$ & yes & yes & yes & no \\
\hline $\begin{array}{c}\text { Approval of operating } \\
\text { surveillance } \\
\text { procedures }\end{array}$ & yes & yes & yes & no \\
\hline $\begin{array}{c}\text { Periodic inspection } \\
\text { 1 year }\end{array}$ & 1 to 5 years & $\begin{array}{c}1 \text { to 10 } \\
\text { years }\end{array}$ & no \\
\hline
\end{tabular}

Table 8: Duties of dam Owners and the Concession Holders in France.

\begin{tabular}{|c|c|c|c|c|}
\hline Duties & A & B & C & D \\
\hline $\begin{array}{c}\text { Complete record of dam design, } \\
\text { construction, and service life }\end{array}$ & yes & yes & yes & yes \\
\hline Register & yes & yes & yes & yes \\
\hline Detailed technical inspection & $\begin{array}{c}1 \\
\text { year }\end{array}$ & $\begin{array}{c}2 \\
\text { years }\end{array}$ & $\begin{array}{c}5 \\
\text { years }\end{array}$ & $\begin{array}{c}10 \\
\text { years }\end{array}$ \\
\hline Operator's report & $\begin{array}{c}1 \\
\text { year }\end{array}$ & $\begin{array}{c}\text { years } \\
5 \leq \\
\text { years }\end{array}$ & no \\
\hline $\begin{array}{c}\text { Instrumentation report } \\
\text { years }\end{array}$ & $\begin{array}{c}\leq 5 \\
\text { years }\end{array}$ & $\begin{array}{c}5 \leq \\
\text { years }\end{array}$ & no \\
\hline $\begin{array}{c}\text { Operating rules (normal operation and } \\
\text { flood period) }\end{array}$ & yes & yes & yes & yes \\
\hline $\begin{array}{c}\text { New design or modifications to be } \\
\text { Damitted to Permanent Committee on }\end{array}$ & yes & no & no & no \\
\hline $\begin{array}{c}\text { Ten-year safety review including full } \\
\text { technical inspection }\end{array}$ & yes & no & no & no \\
\hline Hazard Study & yes & yes & no & no \\
\hline Report any significant events & yes & yes & yes & yes \\
\hline
\end{tabular}


As a result of the new regulations governing dam safety, priorities for repairs and rehabilitation works are based now on the inspection and safety reviews' programs prescribed already, and in view of limited budgets and resources, dam owners who operate and maintain large number of dams such as Electricite de France (EDF) has established the "Super Hydro Program", in which it planed more than 300 maintenance operations between 2007 and 2011, for a total cost of more than 500 million euros (US\$716 million). Most of these operations involve gate or penstock work, such as replacing or refurbishing gates and replacing or painting penstocks in addition to several civil engineering works.

EDF operates about 450 hydro plants with construction dates stretch from the end of the $19^{\text {th }}$ century to 2009 , and the average age is about 60 years. In 2005 and 2006 , several incidents at these plants had happened and results of inspections and reviews showed the need to better detect the progression of aging and to schedule suitable maintenance operations.

As a result of new 2007 regulation, EDF faces the challenge of producing 239 risk assessment studies and 149 periodic safety audits. These studies were due before the end of 2012 for dams classified as A and before the end of 2014 for dams classified as B [20].

\subsection{Dam Safety Guidelines and Legislations in Canada}

Guidelines and Legislations related to dams' safety in Canada, including the regulation on construction, operation, maintenance, and safety issues are provincial/ territorial responsibility unlike some other countries like, UK, France, Mexico, South Africa, etc. Canada does not have a federal regulatory agency or overall program to guide the development of requirements for the safe management of dams. The Federal Government, however, has regulatory requirement over some aspects such as approval of dams to be constructed in navigable waters and dams located on boundary waters with the US and dams constructed and operated by the Canadian's nuclear industry. The Federal Government also has regulatory interests through the Fisheries Act, Species at Risk Act, the Environmental Protection Act, and the Nuclear Safety and Control Act. Moreover, the federal government manages its own dams, which are exempt from provincial regulation such as Parks Canada Dams.

Provincial and territorial jurisdictions generally have their own regulatory framework and guidelines to inform the dam owners/operators about roles and responsibilities, regulatory requirements, processes, and procedures; as well as methodologies for compliance assurance. The provinces of Alberta, British Columbia, Ontario, and Québec have varying degrees of specific regulatory requirements. Some jurisdictions may rely on legislation related to management of water resources and refer to industry best practices as published by the Canadian Dam Association (CDA). This association, a non-profit organization formed in the 1980s, provides dam owners, operators, consultants, suppliers, and government agencies with guidance on issues of dam safety in Canada. The Dam Safety Guidelines and other guidance developed by CDA can provide regulators with a 
basis for evaluating the safety of dams within their respective jurisdictions.

Before any water retaining structure is constructed or modified, the dam owner requires authorization according to the requirement of to the related jurisdiction and its regulatory authority, and there are often different ministries/ agencies in each province or territory that are responsible for water dams and mine tailings dams.

The regulatory framework that governs dams (water and mining) have been enforced in the Canadian provinces and territories of British Columbia, Saskatchewan, Ontario, Quebec, Labrador, the Northwest Territories, and for Dams in Canada's Nuclear Industry. Table 9 illustrates the scope of these legislations, regulations guidelines enforced in British Columbia for water supply dams, and Table 10 does the same for mining dams. These frameworks are similar in many details to those used in other territories [21].

Table 9: Legislations, regulations guidelines enforced in British Columbia for water supply dams.

\begin{tabular}{|c|c|c|c|}
\hline $\begin{array}{l}\text { Legislation/ } \\
\text { Regulation }\end{array}$ & Regulation & Guidelines other than (CDA) & $\begin{array}{l}\sim \text { Number of } \\
\text { Dams }\end{array}$ \\
\hline $\begin{array}{c}\text { Water } \\
\text { Sustainability } \\
\text { Act }\end{array}$ & $\begin{array}{c}\text { Dam } \\
\text { Safety-Regulation }\end{array}$ & $\begin{array}{l}\text {-Inspection and Maintenance of } \\
\text { Dams } \\
\text {-Plan Submission Guidelines } \\
\text {-Consequence of Failure } \\
\text { Classification Guidelines } \\
\text {-Compliance and Enforcement } \\
\text { Policy } \\
\text {-Legislative Dam Safety Review } \\
\text { in BC-APEGBC Guidelines* } \\
\text { - Site Characterization for Dam } \\
\text { Foundations in BC-APEGBC* } \\
\text { Guidelines }\end{array}$ & $\begin{array}{c}1814 \\
\text { Regulated } \\
\text { Dams }\end{array}$ \\
\hline
\end{tabular}

Table 10: Legislations, regulations guidelines enforced in British Columbia for mining dams.

\begin{tabular}{|c|c|l|c|}
\hline $\begin{array}{c}\text { Legislation/ } \\
\text { Regulation }\end{array}$ & Regulation & \multicolumn{1}{|c|}{$\begin{array}{c}\text { Guidelines other than } \\
\text { (CDA) }\end{array}$} & $\sim$ Number of Dams \\
\hline Mines Act & $\begin{array}{c}\text { Mines Act } \\
\text { Health, Safety \& } \\
\text { Reclamation Code }\end{array}$ & $\begin{array}{l}\text {-Dam Safety Inspection } \\
\text { Guidelines } \\
\text {-APEGBC Professional } \\
\text { Practice Guidelines* } \\
\text {-Legislative Dam Safety } \\
\text { Review in BC-APEGBC } \\
\text { Guidelines* }\end{array}$ & 118 \\
\hline
\end{tabular}

Note: APEGBC is the Association of Professional Engineers and Geoscientists of British Columbia. 
Dam safety Acts and Regulations, as established in British Columbia, serve as models for other similar Acts and Regulations in the other Canadian territories. They deal with site surveillance of dams, their formal inspections, and performing tests; by putting responsibility on the owner to assess the condition of the dam during the operation of the dam or the alteration or improvement to or replacement of the dam. This is established by, site surveillance, formal inspection of dams, carrying out of spillway gates and other mechanical components of the dam, and the electrical and communication equipment relating to the dam. The Acts and Regulations require also that these activities be carried out as frequently as specified in schedules attached to the Acts and that all results are documented in reports. Overall safety reviews are also required and reported as frequently as specified.

The regulations charge the Owner with the duty of installing and upkeep of instrumentation. The owner must install the instrumentation necessary to adequately monitor the dam and the area surrounding or adjacent to the dam, maintain or replace the instrumentation when required and ensure continuity of readings. The collected readings have to be analyzed and interpreted and reported no less frequently than is specified in the respective schedule for the classification of the dam. Moreover, an Owner who intends to install, modify, replace, or remove instrumentation relating to the dam must submit detailed plans with time schedules to a dam safety officer for acceptance.

With respect to the safety review of any dam, the Owner is expected to do this in accordance to the risk classification of dam; being, high, very high, or extreme, no less frequently than what is specified in a tables for each of these categories. The Owner has to ensure that an engineering professional who has qualifications and experience in dam safety analysis carries out this review in accordance with the requirements of the controller or a water manager.

The review shall aim to determine if the dam is safe; and, if it is determined that the dam is not safe, to stipulate what actions are required to make the dam safe. The Review Engineer has to prepares, in the form and with the content specified by the comptroller or a water manager, a report on the safety of the dam, and submit to a dam safety officer, for acceptance by the dam safety officer [22, 23].

\section{Summary Points and Conclusions}

1. Dam safety inspections and reviews are impotent safeguards against threats that might endanger any dam, newly built or has been in service for many years. Any anomaly in the behavior of such dam, when early discovered and then investigated and treated, saves the dam from further consequences before things become worse or out of control leading to failure. As a final result this will save the community from fatal losses and damages.

2. Dam inspections, as a first step, are to be performed, by experienced operation personnel. More comprehensive inspections and safety reviews are carried out as next preferably by professional inspection engineers and they have to be done in such frequency which is commensurate with the dam classification hazard 
and its size and importance, and its past behavioral history. Reference to design documents and reports of past performance become as handy tools for comprehensive safety reviews. If any sign of new adverse development appears during the operation of the dam, then dam personnel may call for an urgent review and action to remove the source of the problem or to ease its impact. Immediate inspection and safety review may become also necessary after passing exceptional floods and earthquake events, and in such safety reviews specialists help is required.

3. Notwithstanding the outcome of such reviews, constant monitoring and observations of the dam, the appurtenant structures and the environ have to be continuously made. Follow up seepage water quantities, chemical composition of seepage water samples and piezometric readings constitute vital information on the general health of the dam in the same way as all instrumentation readings and recordings. Between safety reviews, the collected data, its summaries and analyses and photographs taken shall be compiled in a report to be submitted to the dam management with recommendations. This monitoring process shall be considered as a continuous process which shall be reported as frequently as required and at previously specified periods.

4. A good practice would be to include in the dam O\&M manual instructions on the frequency and scope of the monitoring, visual inspections, testing and surveys and to provide checklist of areas of interest with these instructions. Such check list may be revised with passage of time and new items may be added as becomes necessary. Maintenance works shall be based on the outcome of the Dam Safety review reports which are the final outcome of these activates.

5. Instrumentations have been manufactured to cover, wide if not all possible problems or concerns. A well designed instrumentation system in any new dam can yield valuable information during the future life of that dam. Some more instrumentation can be also added if need arises in older dams. The objective is always to have a better overall knowledge of the dam behavior and to reduce risks, and minimizing possible threats.

6. In most countries which have large number of dams, the promulgation of laws and acts dealing with dam safety issues has become the duty of governments of these countries and recognized institutions, and this matter has been taken as one of "Public Concern". Similarly, in these countries, guidelines have been formulated by professional bodies in these countries. Other countries can make use of these laws and regulations in a general way, but they should be tailored according to the circumstances and needs of such countries.

7. The intensive developments witnessed all over the world today, taken with the rapidly accelerating population growth, drives towards constructing more new dams. This may increase the hazards and risks to population and infrastructures; unless such dams are built with all possible safety precautions applied and reviewed. Having grater diligence in observing and reviewing the safety of existing dams, which are aging with the passage of time, can also alleviate great possible dangers in the future. 


\section{References}

[1] Jansen, R.B (1983). Dams and Public Safety. USBR: A water resources technical publication, pp.96-97:

https://www.usbr.gov/tsc/techreferences/mands/mands-pdfs/AZ1130.pdf

[2] Federal Energy Regulatory Commission (FERIC) (2018). Instrumentation and Monitoring. Chapter 9, Engineering Guidelines for the Evaluation of Hydropower Projects. Updated: June 4, 2018 :

https://www.ferc.gov/industries/hydropower/safety/guidelines/engguide/chap9.pdf

[3] Adamo, N. (2020a). Dam Safety and Geology. In the print.

[4] USBR (2000). Safety Evaluation of Existing Dams. Water Resources Technical Publication. First edition 1980, Revised 1983, last edition 2000, pp.18-30.

https://www.usbr.gov/tsc/techreferences/mands/mands-pdfs/SEED.pdf

[5] Adamo, N. (2020b) Dams Safety and problems in Aging Dams. In the print.

[6] Peter, A. P. (2009). Operation of Spillway Gates Avoiding-Avoiding Problems and Pitfalls. 34th Annual Qld Water Industry Operations Workshop, Caloundra 16 to 18 June. http://www.wioa.org.au/conference_papers/documents/PeterAllen.pdf

[7] Veesaert, C.J. and Session, P.E (n.d.). Inspection of Spillways, Outlet works and Mechanical Equipment. Session XV Page 11, US Bureau of Reclamation. https://www.michigan.gov/documents/deq/wrd-dams-inspection-spillwaysoutlets_577396_7.pdf

[8] Federal Emergency Management Agency (FEMA) (2004). Federal Guidelines for dam Safety. Interagency Committee on Dam Safety. Issued in June 1979 (reprint April 2004). https://damsafety.org/sites/default/files/FEMA_FederalGuidelines_93.pdf

[9] Government of India (2018). Guidelines for Safety Inspection of Dams. Central Commission, Ministry of Water Resources, River Development and Ganga Rejuvenation. https://damsafety.in/ecmincludes/PDFs/Guidelines_for_Safety_Inspection_of _Dams.pdf

[10] Queens Land Government (2018). Dam Safety Guidelines and Requirements. Business Queensland website retrieved on 5th May 2020. https://www.business.qld.gov.au/industries/mining-energywater/water/industry-infrastructure/dams/safety-guidelines-requirements

[11] USACE (n.d). Dam Inspection. U.S. Army Corps of Engineers Headquarters Website. Retrieved on 5th May 2020. https://www.usace.army.mil/Missions/Civil-Works/Dam-SafetyProgram/Program-Activities/ 
[12] FEMA (2004). Federal Guidelines for Dam Safety. US Department for Homeland Security. Interagency Committee on Dam Safety, June 1979 Reprinted in April 2004 https://damsafety.org/sites/default/files/FEMA_FederalGuidelines_93.pdf

[13] The British Dam Society (n.d.). Dam Safety-The Dolgarrog Disaster, 1925”. Retrieved on 8th May 2020. https://britishdams.org/about-dams/dam-information/safety/

[14] Jesic, J. (2018). Maintaining the safety of our Raw water reservoir. Severn Trent Raw Water Reservoir Surveillance Training Manual, pp.31,63. https://britishdams.org/assets/documents/Web\%20Ref\%20Docs/2019_03_04 _Maintaining\%20Reservoirs_\%20Redesign.pdf

[15] American State Dam Safety Officials (n.d.). Dam Failures and IncidentsLearning from The Past: A Snapshot of Historic U.S. Dam Failures. Retrieved on 9th May 2020. https://damsafety.org/dam-failures

[16] Federal Emergency Management Agency (2014). Dam Safety in the United States. A Progress Report on the National Dam Safety Program Fiscal Years 2012 and 2013. Published in 2014. https://www.fema.gov/media-library-data/1467048771223c5323440700a175565a2c0c9d604f9e3/DamSafetyUnitedStatesAug2014.pdf

[17] U.S. Army Corps of Engineers Headquarters Website (n.d.). Dams Inspections. Program Information. Retrieved on 9th May 2020. https://www.usace.army.mil/Missions/Civil-Works/Dam-SafetyProgram/Program-Activities/

[18] João, F. A. S. (2010). Small Dams, Design, Surveillance and Rehabilitation. ICOLR ad hoc Committee on Small Dams. Small Dams Bulletin, December 2010. http://docshare.tips/download/576574e6b6d87f87b68b4ce2 dokumen. site_icold-small-dams-sept-2011

[19] McGrath, S. (2000). To study International Practice and use of Risk assessment in Dam Management. Canberra: Winston Churchill Memorial Trust of Australia 2000. https://www.usbr.gov/ssle/damsafety/risk/churchillreport.pdf

[20] Petitjean, A. and Denis, B. (2009). Hydraulic Structures: Dam Safety progress and Challenges at Electricite de France. HydroWorld 10th January 2009. https://www.hydroworld.com/articles/print/volume-17/issue5/Articles/hydraulic-structures.html

[21] Canadian Dam Association (2016). Regulations of Dams in Canada. June 2016. Retrieved on 11th May 2020. https://www.cda.ca/En/Dams_in_Canada/Regulation/EN/Dams_In_Canada_ Pages/Regulation. aspx?hkey=9f7a09f5-19be-4c40-8e-4e-7eee628a7f50 
[22] British Columbia Government (2016). Dam Safety Regulation-Water Sustainability Act. British Columbia Canada, Victoria, Deposited February 29, 2016, effective February 29, 2016.

http://www.bclaws.ca/civix/document/id/complete/statreg/40_2016\#division_ d0e1123

[23] British Columbia Government (1998). Inspection and Maintenance of Dam Safety Guidelines. Water Management Branch. https://www2.gov.bc.ca/assets/gov/environment/air-land-water/water/damsafety/2016_new_body_with_index_and_cover-final.pdf 